David Wilson

Piracy, Patronage \& Political Economy: Captain Kidd and the East India Trade

School of Humanities, University of Strathclyde, Lord Hope Building, 141 St. James Road, Glasgow G4 0LT

$+44(0) 1414448219$

david.wilson.101@strath.ac.uk 


\title{
Piracy, Patronage \& Political Economy: Captain Kidd and the East India Trade
}

\begin{abstract}
At the end of the seventeenth century, Whig and Tory debate over the organisation and future of the East India trade recognised the need for a closer relationship between merchant and state. However, the existence of an illicit pirate enterprise between New York, Madagascar and the Red Sea proved an obstruction to the future of this trade. This article seeks to explore the ill-fated voyage of Captain William Kidd of 1696-99 during which Kidd was commissioned to confront the Red Sea marauders as part of the state's war on piracy. It will be argued that in the process, he became intertwined with the development of political economy in post-revolution England and ultimately, became the necessary catalyst and martyr for political and economic change.
\end{abstract}

Keywords: pirates, piracy, patronage, political economy, captain kidd, east india trade

\section{Introduction}

In 1701, the body of Captain William Kidd was suspended at Tilbury Point on the Thames in London. Kidd was a victim of the war on piracy mounted by the government against the geographic expansion of piratical activity from the Caribbean to the Red Sea and Indian Ocean. ${ }^{1}$ Over the last decade of the seventeenth century, the Indian Ocean and the Red Sea became the major haunt of European pirates. The majority of these pirates made their way from the Caribbean, where they could no longer expect to receive patronage from colonial governors, to the North American colonies. Certain North American colonial officials, particularly Governor Benjamin Fletcher of New York, and prominent merchants, such as Frederick Phillips, were willing to illicitly sponsor piratical voyages to the Indian Ocean where pirates targeted the pilgrim fleet that sailed from Surat in India to Mocha and Jeddah on the Arabian Peninsula. ${ }^{2}$ Kidd was sponsored by the Whig Junto to lead an expedition against the pirates marauding in the East. During the expedition, Kidd supposedly turned pirate and, in the process, became a political pawn to be utilized against the Junto. Robert C. Ritchie argued that William Kidd became entangled in the rivalry between the Whigs, Tories and the East India Company in postrevolution England. Ritchie's work remains one of the seminal studies in the historiography of piracy. This article aims to expand on Ritchie's analysis by highlighting how Kidd inadvertently became a central figure in the debate concerning political economy in post-revolution England. The importance of this study relies on utilising Steve Pincus' pioneering argument concerning a new political economy in England after the Glorious Revolution. Pincus argues that the development of a new political economy was an intentional goal of the revolution and, for much of the following decade, Whig and Tory disagreement over political economy fuelled intense debate in parliament. ${ }^{3}$ The Whig leadership, known as the Junto, were targeted by the Tories and the East India Company for endeavouring to restructure the East India trade to correspond with their perceptions of political economy. An analysis of Kidd's 16961699 voyage within this wider context will offer new insight into the reasons why 
government policy towards piracy changed so dramatically during the 1690s. Kidd's fate became intertwined with economic and political change as England emerged as a modern economic powerhouse at the turn of the century.

\section{Patronage, Political Economy \& Enterprise: William Kidd, Robert Livingston and the Whig Junto}

In 1695, Kidd sailed from New York to London with the intention of entering the king's service by securing a letter of marque. By this time, Kidd had already been captain of a privateering ship during King William's War and had settled in New York where he secured the favour of Robert Livingston, a prominent merchant and landowner. ${ }^{4}$ Livingston had journeyed to the entrepôt of empire earlier in 1695 to settle a monetary dispute with Benjamin Fletcher, the governor of New York since 1692. ${ }^{5}$ The fact that Livingston travelled to London in an attempt to settle his dispute highlights the importance of political patronage in Anglo-American politics. New York politicians were directly dependent upon their English connections; colonial politics were won and lost in England. When changes occurred in the balance between English parties, or certain politicians lost influence or power, this would be reflected in the fortunes of their counterparts in the colonies. ${ }^{6}$ Therefore, Livingston and Kidd arrived in London at a particularly interesting time in English politics as the leaders of the Whig party, known as the Whig Junto, had secured the majority of offices in King William's administration.

The Whig Junto rose to power after 1693 when William grew dissatisfied with the Tories' contempt for the costs of the French War. The Whigs supported the war effort, and won William's favour by supporting the creation of the first central bank, the Bank of England. ${ }^{7}$ Steve Pincus argues that the creation of the bank would not have been possible without a prior revolution in political economy that was central to the agenda of the revolution of 1688-1689. The transformation of political economy was a consequence of a heavily politicised argument between two rival economic programs. Both the Whigs and Tories desperately wanted the state to intervene in economy, and wanted the post-revolutionary state to support their respective economic programs. At the core of Whig notions regarding political economy was the question of the East India trade. The Whigs had been supporters of East India interlopers, as they believed the monopolies held by the East India Company were harming England's manufacturing society. ${ }^{8}$ Thomas, Lord Wharton, and Charles Montague, two prominent Junto figures, led the assault on the East India Company with accusations of bribery levelled at leading Tory members of the Company. The investigations proved inconclusive but succeeded in tarnishing the reputation of the Company and the politicians involved. The scandal of the bribery inquiries contributed to the parliamentary suspension of October 1695 and the election of a new House of Commons that was heavily controlled by the Whigs who approved the dissolution of the Company. ${ }^{9}$ When Kidd and Livingston arrived in London in 1695, the Whigs were at the height of their power. However, the issue of political economy had gained the Junto two powerful enemies: the Tories and the East India Company. Both would work together to enact revenge on the group who planned to disrupt their influence and trade: Kidd would prove valuable to their designs. 
Although the Whigs proposed to restructure the East India Company, they did not want to halt East India trade altogether. They believed the primary benefit of the trade was to provide the metropole with raw materials. The Whigs' main agenda was to create a new company that was regulated by them in compliance with their economic program. A major hindrance to the East India trade was the existence of an outpost on St Mary's Island, Madagascar, which sustained an illicit trade between New York merchants and the Red Sea pirates. ${ }^{10}$ Piracy was a major issue for the Whigs who viewed pirates as an obstacle to the future prospect of the trade. They would need to be eradicated. A proposal was laid out by Kidd, Livingston and Richard Coote, the Earl of Bellomont, a leading Whig and future governor of New York. The proposition offered an end to the illicit pirate trade and the promise of vast profits for the Junto. ${ }^{11}$ This scheme would turn out to be "one of the greatest political blunders of the era."12

The origins of the scheme remain uncertain because each participant attempted to place blame elsewhere when the plan went askew. It seems certain that Kidd and Livingston concocted the plan and presented it to Bellomont. ${ }^{13}$ The proposal was to fit out a ship powerful enough to make an expedition against the pirates. Kidd, in command of the ship, was to seize marauders in the East Indies and confiscate their rich and illicit cargos. This would help eradicate the hindrance on the East India trade but would also provide hefty revenue for the partners of the voyage. ${ }^{14}$ Although this agreement was officially between Kidd, Livingston and Bellomont, the latter represented the hidden partners of the expedition: Henry Sidney, first Earl of Romney, master general of ordnance; John, Lord Somers, Lord Keeper of the Great Seal; Edward Russell, first Earl of Orford and Admiral of the Fleet and Treasurer of the Navy; and Charles Talbot, first Duke of Shrewsbury and Secretary of State for William. They were four prominent members of the Junto, who were currently holding several of the highest offices of government and were represented on the various documents by their servants. ${ }^{15}$ The scheme offered the Junto members a private and potentially profitable enterprise that would help resolve the problem of piracy in the Red Sea and Indian Ocean. ${ }^{16}$ After the articles of the agreement were signed all that was left to do, while the Adventure Galley was purchased and fitted out for the voyage, was acquire the commission needed to make the proposal legal.

Acquiring the commission was a lengthy and complex matter. Initially, the partners applied to the Admiralty for a privateering commission that only allowed Kidd to seek out enemies of the state. The difficulties arose when the partners sought a commission to hunt pirates aand seize their cargo. Orford submitted the request for this but the Lords of Admiralty questioned the legality of such a commission and forwarded it to Sir Charles Hedges, Chief Judge of the Admiralty Court, to decide. The partners resolved to secure the commission elsewhere. The commission was requested under the Great Seal of England. On 26 January 1696, the Lord Keeper of the Great Seal, John, Lord Somers, one of the four hidden partners, issued the patent. Both commissions were obtained, and Kidd's proposed expedition could proceed legally. ${ }^{17}$ Kidd departed in late February 1696 with two commissions, a fully sponsored expedition, and the patronage of some of the most powerful men in England and the future governor of his adopted home in New York. ${ }^{18}$ Kidd was to realise the consequence of such patronage when he returned four years later. 


\section{"There never was a greater Lyar or thief in the world than this Kidd"19: The ill- fated voyage of Captain William Kidd}

The full voyage of Kidd is well covered by Ritchie. However, it is necessary to examine the key events that shaped Kidd's fate to provide the reasons why he became entangled in the debate concerning political economy. These key events were: his encounters with Commodore Thomas Warren and John Clerke; his brief sojourn at Karwar; and his piratical activities off the Malabar coast. Providing an account of Kidd's voyage is problematic and only possible using fragmentary and often contradictory accounts given by captured crew members, East India Company officials, and Kidd himself. Furthermore, there is no survivng journal of the voyage despite this being a stipulation of the agreement between Kidd and the Junto. According to Kidd, this journal was stolen by his supposedly mutinous crew in Madagascar near the end of the expedition. ${ }^{20}$ No other account mentions that Kidd's journal was stolen or destroyed. Thus, it is plausible to suggest Kidd fabricated this version of events to justify his inability to produce an accurate journal. This allowed him to shape a narrative of the voyage that, on his return, would proclaim him innocent as any journal he had kept would disclose his trangressions. Therefore, Kidd's narrative, given to Bellomont when he was apprehended, cannot be trusted as he intentionally left out crucial details of his voyage that would have proved detrimental to his case. Likewise, the accounts of detained members of his crew and East India Company officials need to be scrutinised carefully as they were as equally self-serving.

On 12 December 1696, en route to the Cape of Good Hope, the Adventure Galley met four English Men of War commanded by Commodore Thomas Warren. ${ }^{21}$ Warren had been assigned to escort the 1696 East Indies fleet on its outward-bound voyage. ${ }^{22}$ Piracy had become a significant concern of the East India Company after Henry Every plundered the Ganj-i-sawai, a large trading vessel owned by the Grand Mughal Aurangzeb in September 1695. Every arguably became the most successful and, undoubtedly, the most wanted pirate of the decade. The Company suffered the repercussions of this raid when the Mughals embargoed their trade and besieged their factory in Surat. ${ }^{23}$ The embargo continued until the Company agreed to protect Indian shipping. ${ }^{24}$ This became common practice of the Mughals: when they received word of a pirate attack on one of their vessels they would siege one of the Company's factories in retaliation. By the middle of July 1696 news of Every's exploits had resonated throughout India and back to the metropole. The Company faced financial ruin on two fronts: in India if the Mughals continued to cut off trade every time there was a piratical attack; and in the metropole while the Whigs struggled to restructure the East India trade. Furthermore, the Company failed to capture Every who disappeared and never resurfaced. ${ }^{25}$ The Company needed to seize an infamous figure like Every to prove to the Mughals that they were suppressing the pirates.

According to Kidd's narrative of the voyage, the Adventure Galley sailed with Warren and the Royal Navy vessels for a week and then parted to sail to Tulear in Madagascar. ${ }^{26}$ Kidd's narrative begins to deviate from other accounts at this point. According to John Clerke, commander of the East India Merchant, Kidd did not simply 
part with Warren. Warren had lost a great deal of men on his voyage and told Kidd that he needed to take some of his crew as was his right. Kidd agreed to this but at the first opportunity rowed away in the night so that by morning he was out of sight and did not have to give up his men. This was extremely injurious to Kidd's future as Warren informed the Company of these events, and highlighted his suspicions of Kidd's design. ${ }^{27}$ This led to the beginning of the Company's campaign to slander Kidd's name. From this event, Company officials kept a close eye on Kidd's voyage, compiling reports and evidence against him to send back to the metropole.

The next incident that added to the Company's campaign was the encounter between Kidd and Clerke at Moheli, one of the Comoros Islands. ${ }^{28}$ The Comoros had offered another refuge for pirates, even when Madagascar was the preferred option. The Sultans of Comoros were willing to trade with newcomers and pirates in order to enhance their own defences. ${ }^{29}$ It is possible Kidd could have been searching for pirates in these havens, however, as he had completely bypassed St. Mary's Island, the primary refuge of the pirates, this seems unlikely. Instead it appears that Kidd stopped at the Comoros for provisions and to careen the Adventure Galley. Clerke states that Kidd declared at this juncture that he was bound for St. Mary's to find pirates whose plunder would "make his Voyage"..$^{30}$ However, Clerke reported that Kidd's crew had divulged to members of his crew that they had only expected to meet one ship in the Comoros, the East India Merchant, and that they gave ambiguous answers when they were asked if they would have attacked the ship if it appeared alone. ${ }^{31}$ His men may have disclosed that they would have taken the ship, but it is doubtful that this would have occured. At this early stage in Kidd's voyage, it is unlikely that he planned to act contrary to his commission. However, that the East India Company propagated this was his intention suggests that even at this point they were starting to build a propaganda campaign against Kidd.

According to Kidd's narrative he sailed for the Coast of India on 25 April 1697 and arrived at the Coast of Malabar at the beginning of September. ${ }^{32}$ However, the actual events that took place in this period, those which Kidd fails to mention at all, would shape his fate. Kidd's purpose in the Red Sea might have been to cruise for pirates and French privateers as stated by Hugh Parrot, one of Kidd's crew, but his actions reveal his true intent. ${ }^{33}$ Kidd sailed to Babs-al-Mandeb, the entrance to the Red Sea, and lay off one of the small islands in the narrows for five weeks in anticipation of the Mocha pilgrim fleet. ${ }^{34}$ This was Kidd's envisioned target all along. One account states Kidd said several times that he "hoped to make his voyage and to ballast his ship with silver and gold" by taking a rich prize from the Mocha fleet. ${ }^{35} \mathrm{It}$ is hard to discern what Kidd's strategy was but it is likely he thought that the large riches he would plunder would encourage Bellomont and his patrons to turn a blind eye to the whole affair. ${ }^{36}$ On 15 August, the Adventure Galley sailed in the midst of the Mocha fleet ready to prey on an exposed merchant ship. However, as the Mughals had demanded, the fleet was protected by both a Dutch and English convoy. Kidd was forced to flee when he realized the English convoy, Sceptre, was bearing down on him. ${ }^{37}$ Having successfully escaped, he made his way to Karwar on the Malabar Coast. Although it appears his design was to do so, Kidd had not yet committed an act of piracy. This changed on the journey to Karwar when a Mughal ship flying English colours was spotted, chased and forced to parley. 
Whilst they plundered the ship, the crew were tortured to reveal where they had hidden their goods. ${ }^{38}$ As the vessel was neither French owned nor a pirate ship, Kidd had formally turned pirate: he had seized a ship illegally and allowed the crew to be tortured.

By the time he arrived in Karwar, the East India Company had already circulated Clerke's report to warn their factories to be suspicious of Kidd. ${ }^{39}$ At Karwar, the factory demanded that Kidd return Thomas Parker, the captain of the Mughal ship, and a Portuguese sailor who had been detained on the Adventure Galley. Kidd denied he had taken them, replenished with wood and water and departed. ${ }^{40}$ However, during this time, nine of his men escaped the Adventure Galley. Two of the escapees, Nicholas Alderson and Benjamin Franks, were detained and sent to the General at Bombay to give their account of Kidd's voyage. ${ }^{41}$ Alderson stated they left the ship when they "found ourselves happan'd \& to be with a Pyrate instead of a Privateer". ${ }^{42}$ Thus, the men claimed to have left following the realisation that Kidd's design was to go marauding instead of privateering. Alderson and Franks were questioned in Bombay and subsequently sent back to England to be examined before the Admiralty Court. ${ }^{43}$ These were not the depositions of desperate pirates but appear to be the honest accounts of men who had expected to participate in a licit voyage, only deserting Kidd at the first opportunity after his piratical acts. The Company had succeeded in apprehending witnesses to blacken Kidd's name and provide evidence that he had turned pirate. Kidd found himself in a desperate situation. He could no longer expect to conceal his questionable behavior but he had not accumulated enough capital to appease his patrons who he would need to support his case when he returned. Between September 1697 and February 1698, the Adventure Galley cruised along the Malabar Coast and during this time, Kidd committed the four major offences that would cement his demise. ${ }^{44}$

The first was the murder of William Moore, the gunner of the Adventure Galley. ${ }^{45}$ At his trial, Kidd argued he had done so to prevent a mutiny after he had refused to take the Loyal Captain, an English ship the Adventure Galley had crossed paths with. ${ }^{46}$ Robert Bradinham and Abel Owens, two members of Kidd's crew used as witnesses during his trial, confirmed the story of proposed mutiny. Kidd's justification for striking Moore was that he had been part of the munity. ${ }^{47}$ However, Moore's death occurred three to four weeks after the incident with the Loyal Captain. Kidd attempted to claim there had been a Dutch ship nearby, and that Moore had conspired to start another mutiny in order to take it, but the witnesses at the trial agreed there was neither a second mutiny nor a second ship. ${ }^{48}$

The second offense was a supposed act of piracy against the Rupparell, a Dutch owned ship of about 150 tons, commanded by a Dutchman, Michael Dickers. Kidd demanded to see Dickers' pass from Surat, which he recognized to be a French pass. Technically, this meant that the Rupparell was a legal prize as Kidd had a commission against French vessels. However, the Rupparell had multiple passes on board, as was common practice among merchants. Kidd had been cruising with the French flag which deceived Dickers into producing his French pass. ${ }^{49}$ Nevertheless, Kidd must have been relieved that he had finally taken a prize he could substantiate as legal. The next ship plundered, however, could not be considered a legal prize. In January 1698, Kidd seized and plundered a Portuguese ship. ${ }^{50}$ At this stage of his voyage, Kidd must have decided that it was more important to plunder as many goods as possible rather than stay within 
the terms of his commissions. After all, he was supposed to be hunting pirates not French merchant vessels. At the trial concerning the murder of Moore, Bradinham alleged Kidd had stated: "I do not care so much for the Death of my Gunner as for other Passages of my Voyage; for I have good friends in England, that will bring me off for that." ${ }^{51}$ Although somewhat speculative, it is probable Kidd thought he would be able to escape any repercussion if he pleased his powerful patrons in England.

The Quedagh Merchant was to prove Kidd's most lucrative and precarious prize. It was a large merchant ship returning to Surat containing a large cargo estimated at a value of between 200,000 and 400,000 rupees. ${ }^{52}$ On 1 February 1698, The Adventure Galley gave chase flying decoy French flags. The Adventure Galley came up with the Quedagh Merchant and commanded the master on board. ${ }^{53}$ The master of the Quedagh Merchant, an English captain named John Wright, sent his gunner, a Frenchman, onboard the Adventure Galley, to present a French pass to the assumed French vessel. When the gunner came on board the Adventure Galley and showed Kidd the pass, Kidd immediately ordered the English flag to be hoisted. ${ }^{54}$ Kidd had finally found the ship that was to make his fortune. In his narrative, Kidd claims that the ship was then delivered to him as a prize to be carried off. ${ }^{55}$ However, this was not all that occurred. There are inconsistent accounts of what happened next, one of which stated that Wright came on board as the true master of the Quedagh Merchant and informed Kidd that the ship and cargo belonged to England. According to this account, Kidd then proposed to his men that they should return the ship as the taking of such a great vessel in the employment of the English would "make a great noise in England". ${ }^{56}$ The crew refused his proposal, as they sought to acquire a share of the vast riches the ship contained. ${ }^{57}$ Another account claims that the Quedagh Merchant was owned by Armenian merchants who offered twenty thousand rupees as ransom for the ship. ${ }^{58}$ Whatever the case, it is clear that Kidd knew the ship was not an entirely legal prize. However, he had secured a French pass, and could use that to justify seizing her. He might have considered letting the ship go but in such a scenario there is little doubt that his men would have turned mutinous and seized the ship regardless of his orders. This was the ship that could make the entire voyage worthwhile for many of the crew and they would not have been willing to let their fortunes sail away from them. Kidd took the Quedagh Merchant as a prize and carried off its immense cargo containing between 60 and 80 chests of opium, 20 to 30 bales of silks, 200 or 300 bales of sugar, and 500 or 600 bales of calicos, muslins, and other East India goods. ${ }^{59}$

Kidd had arrived in the Indian Ocean already under the suspicion of the Company who required the capture of an infamous figure to symbolize the war on piracy for the Mughals. They had started to build a campaign against Kidd ever since the incident with Warren. They needed a scapegoat to protect the East India trade and Kidd could provide this. However, the taking of the Quedagh Merchant was more than the Company could have expected. The ship was leased out to Muklis Khan, a leading member of Aurangzeb's court. The loss of this investment caused outrage at the emperor's palace. The English factory in Surat was threatened by infuriated mobs, and their trade was cut off once more. Aurangzeb commanded that the Company compensate the investors in the Quedagh Merchant, and provide better convoying for Mughal ships. ${ }^{60}$ The seizing of the Quedagh Merchant had placed the East India trade in jeopardy and dealt the Company a serious setback. Kidd was no longer a potential 
scapegoat, but could be actively promoted as an infamous figure. Kidd left the Indian Ocean with the full weight of the East India Company bearing down on him. His links to the political powers in England could not save him, but would only prove more ruinous to his case as the Company and Tories united to bring down the Junto, placate the Mughal court, and save the East India trade. Kidd was the central element in their combined campaign; he needed to be captured and paraded as an agent of the Junto and a symbol of the war on piracy.

\section{"Because I would not turn Pirate, you Rogues, you would make me one" ${ }^{61}$ : Capture, Trial and Execution.}

After dividing the booty of his voyage at Madagascar, Kidd returned from the India Ocean via Madagascar in the Quedagh Merchant, renamed the Adventure Prize. A number of his men had left him to join the crew of Robert Culliford, a well known pirate, who Kidd had encountered at Madagascar. According to Kidd, his crew had mutinied against him after he proposed to seize Culliford's vessel. Kidd's entire narrative at Madagascar is inflated and self-serving. All other accounts suggest that Kidd received his designated 40 shares of the plunder which makes any account of mutiny highly unlikely. ${ }^{62}$ Kidd arrived at Anguilla at the beginning of April $1699 .{ }^{63}$ Kidd, alongside the men who returned with him, asserted that this was when they discovered they had been proclaimed pirates. ${ }^{64}$ Kidd must have known before then that his actions would have been reported and known to his patrons. However, when he arrived at Anguilla he discovered that a royal proclamation had been given on 8 December 1698 which permitted all pirates a pardon if they gave themselves up; all that is, except Henry Every and William Kidd. ${ }^{65}$ Kidd found himself declared a pirate, and one as notorious as Every. ${ }^{66}$

Kidd left the Adventure Prize in the possession of Henry Bolton, a merchant from Curacao, and purchased a sloop, the Saint Antonio, from him. Kidd promised to return in three months to collect the rest of the goods. ${ }^{67}$ The fact that Kidd planned to return after calling at Boston shows he held faith that his patron, Bellomont, would be willing to shelter him and vouch his innocence. Next, Kidd offloaded goods at Delaware Bay, Gardiners Island, and Tarpaulin Cove whilst corresponding with Bellomont. Through his friend James Emott, Kidd submitted an offer to Bellomont that he would land at New York if he would be pardoned. Emott preached Kidd's innocence and delivered the two French passes that Kidd had secured. Emott informed Bellomont that Kidd had left a great Moorish ship on the Coast of Hispaniola that contained goods to the value of thirty thousand pounds. Bellomont sent word to Kidd promising him a kind reception if he were to come into Boston and that he would get him the King's pardon if he was as innocent as he claimed to be. Kidd landed in Boston on 1 July to plead his case, trusting that his patron desired his share of the investment and, therefore, would secure him a pardon. ${ }^{68}$ However, Bellomont had never intended to support Kidd but rather to deceive him. Kidd was examined before the Council two or three times before being apprehended and detained on 6 July. ${ }^{69}$ On 2 February 1700 Kidd and his men were confined on the frigate Advice for the return journey to London. ${ }^{70}$

Kidd arrived in London to a completely different political atmosphere than he had left four years previously. By 1699, the Whig Junto were rapidly losing influence. The 
country had been discontented with continual high taxes enacted to fund the Nine Years War and dreaded the prospect of sustaining a large standing army after the war. When parliament was recalled in November 1699, the Tories were organized to expel the Junto from power and knew the Kidd issue could provide the crushing blow. ${ }^{71}$

Kidd's fate was to be shaped by political economy. The East India Company had been targeted by the Junto since the revolution. In 1697, the East India Company offered a loan of $£, 700,000$ to the king in return for an act of parliament that would secure their monopolistic control of the East India trade. The Junto firmly backed the opposing interlopers who made a counter offer of a loan for $£ 2,000,000$. The members of the Junto convinced the king to agree to their proposal. In 1698, Montague mobilized his influence to pass a bill establishing the New East India Company under control of a syndicate of interlopers, but allowing that anyone could subscribe to join the New Company. Even the Old East India Company was forced to subscribe to the New Company after it was given notice that it would be dissolved in three years. ${ }^{72}$ After 1698 the New Company had parliamentary sanction for monopolistic control over East India trade. ${ }^{73}$ This ushered in a new era of commercial policy; one where parliamentary iniative was in charge of shaping commercial policy as opposed to royal prerogative and court patronage. In order to preserve their priveleged status, companies now needed firm parliamentary support. ${ }^{74}$ The Junto had secured the demise of the Old East India Company. The Old Company needed to mobilize or face losing all influence. The Old Company had already built a campaign against Kidd; his capture could finally help to satisfy Aurangzeb and the Mughal court. Moreover, his links with the Junto could provide the Old Company with exactly the ammunition they needed to blacken the reputation of the patrons of the New Company. Kidd was an essential instrument in the Company's strategy to regain monopolistic control of the East India trade.

News of Kidd's appearance and arrest in Boston reached England by August 1699. Charles Vernon reported as early as 8 August 1699 that the Old East India Company had became very inquisitive after Kidd. ${ }^{75}$ When it was officially confirmed that Kidd was imprisoned, the Old Company appeared in full before the Lords Justices to request Kidd's plunder to satisfy those who had suffered because of his piracies. ${ }^{76}$ Vernon noted, somewhat prophetically that "so many of those principal men appearing on this occassion, shews they intend to make all the bustle about it they can." ${ }^{77}$ In December, the issue of Kidd was discussed in parliament. The Tories, with support from the Old Company, led the attack on the Whigs declaring that Kidd "plundered with a commission under the Broad Seal in his pocket". ${ }^{78}$ The Tories claimed Kidd had been encouraged to commit piracies by the Junto partnership who had "sent out their thieves to rifle whatever was to be met with elsewhere". ${ }^{79}$ In addition, they argued that the commission granted under the Great Seal to take pirates and keep their goods should be declared void. According to them, the provision was illegal because illicit goods were not grantable; they did not belong to the pirates but to whomever they had been seized from. This political attack was entirely targeted at Somers who had been Lord Keeper of the Great Seal and had approved the commission. The Tories wanted to remove Somers from power because he was one of the last members of the Junto to hold a powerful and influential office. The issue of the legality of the commission was debated on 7 December 1699 with the result that the goods were found grantable, and the commission 
legal. ${ }^{80}$ But while the Tory attack had failed to oust Somers from the House of Commons, it had damaged his reputation and brought the issue of Captain Kidd to an undeserved place at the fore of politics.

Kidd arrived in London on 14 April 1700 where he was brought to the Admiralty building and examined from $4 \mathrm{pm}$ until $11 \mathrm{pm}$. However, he did not deviate from his previous statements. He gave an account of his owners and the costs of fitting out the Adventure Galley, stating that he had never met Somers or Shrewsbury but had met Romney once and Orford more often. This was not the account that the Tories had hoped for. The members of the Junto had already admitted to their investments in the voyage, the information that Kidd gave only verified their reports. ${ }^{81}$ Kidd's account did not provide the Tories or the Old East India Company with any extra evidence to use against the Junto. In fact, Kidd's impartial examination took suspicion away from the Junto and it is probable that he continued to believe his patrons would protect him from harm. ${ }^{82}$. However, Kidd was sent to Newgate prison, normally reserved for criminals who had committed treason, and kept in close confinement. He was not allowed visitors in case any of the interested parties attempted to interview him. ${ }^{83}$ The fact that Kidd was held in Newgate as opposed to Marshalsea, the regular destination for pirate captives awaiting trial, emphasises his undeserved place of political importance at the time. The Kidd issue became entangled with political rivalries and economic policy concerning the East India trade. Kidd was a pawn in the deadly game of post-revolution partisan politics. His supposed patrons, the Junto, who were accountable for his fate were unwilling to help him but left him confined in Newgate, declined to contact him, and waited for the day he would be arraigned and the whole affair concluded.

It was not until late April 1701, approximately a year after his imprisonment, that Kidd was granted the papers needed to prepare his case. ${ }^{84}$ However, the two vital pieces of evidence for Kidd's defence, the French passes from the Rupparell and the Quedagh Merchant, had disappeared. ${ }^{85}$ Kidd would later claim that Bellomont had witheld the evidence to secure his downfall; but as the passes were discovered in the records of the Board of Trade in London in the twentieth century it seems likely that Bellomont had sent them with the rest of the papers concerning Kidd. It is impossible to discern if the passes were genuinely lost for a time or if someone like Vernon, who had access to all of the papers relating to Kidd, withheld them to secure Kidd's fate. With little defense, the trial would move along swiftly to the great benefiit of the Junto. The last thing that the men involved needed was for the jury to acquit Kidd based on the evidence of the passes. ${ }^{86}$ The issue of the French passes is one reason that Kidd's innocence has become so widely speculated. Were the passes deliberately 'misplaced' to ensure Kidd would be found guilty? This question is important but even if Kidd had full access to the passes, his fate had already been decided. Kidd was too infamous a prisoner to be allowed to walk free. He had become entangled in the changing politics of the decade; he had made enemies of the Tories by proxy of his patronage with the Whigs, and had provided the Old East India Company with the martyr they needed to appease the Mughal Court and obstruct the New Company.

The trial of Captain Kidd and his crew took place over two days, 8 and 9 May 1701. Kidd was found guilty of the murder of William Moore, and of piracy against the Quedagh Merchant, the Rupparell and the Portuguese ship he had taken in early January 
1698. Over the two days, Kidd was declared guilty on four cases that held the sentence of capital punishment. Even if Kidd had produced the French passes, he would not have escaped the sentencing from the other two cases. On the second day of the trial, Kidd was condemned to death. ${ }^{87}$

The issue of the French passes, although curious, is not imperative. It is evident that Kidd was guilty of at least two of the cases brought against him. The fact remains that too many powerful figures desired Kidd's death. The Junto needed this issue concluded as they had already lost the majority of their power after a Tory-controlled parliament had returned in the spring of 1701. The Kidd issue had helped deal the final blow as expected. ${ }^{88}$ The Tories wanted Kidd prosecuted to further blacken the reputation of the Junto. The Old East India Company needed Kidd's death to appease the Mughals and to begin reestablishing their dominance over the East India trade. Tory dominance meant a much friendlier political atmosphere for the Old Company. In late December 1701, the Old and New Companies ratified articles that laid the basis for the eventual amalgamation of the two corporations. Although this union was not formally achieved until 1709, the East India trade came under the joint management of a committee composed of equal numbers of directors from the two companies after $1702 .^{89}$ The issue of control of the East India trade was finally resolved. The opposing Whig and Tory economic programs had led to a settlement that allowed the East India trade to flourish under the sponsorship of parliament. Kidd had been a victim of the issue of managing international trade; only his capture and prosecution had enabled the correct political environment to resolve this issue to the benefit of the Old Company.

Kidd was executed on Friday, 23 May 1701. In his last speech, he condemned those who had been witnesses in his trial as liars, and denounced those who had promised they would be his friends and had led to his ruin. To the surprise of Kidd and the spectators, the rope that held him broke when he dropped. The hangman grabbed him, carried him back up the ladder, and sent him to his death a second time. ${ }^{90}$

\section{Conclusion}

This article has sought to expand on Ritchie's scholarship by arguing that the revolution in political economy after 1688 created the opposing economic programs which shaped the political atmosphere that William Kidd fell victim to. After the Glorious Revolution, partisan politics came to the fore of the political system. Debates over political economy transformed England into a modern economic powerhouse. The East India trade could no longer be managed outside of government control by a monopolistic company that burdened the manufacturing societies in England. The Junto had actively intervened to advance their own economic program that opposed this burden. They attempted to regulate the company to fit their objectives. The result of this was the consolidation of a closer relationship between merchant and state. ${ }^{91}$ As international trade became interwoven with politics, the government clamped down on the hindrances to trade; namely, the Red Sea pirates. Kidd was ensnared in these developments. He was sponsored to eradicate the pirates, but instead became the necessary catalyst and martyr for political and economic change. Kidd was hunted and executed as a political instrument of the Tories and as a necessary sacrifice to secure the East India trade from 
Mughal hostility. His fate was entwined with the establishment of greater parliamentary control over commercial policy at the turn of the century. Kidd, an alleged pirate, undeservedly became a central character of the East India debate and the war on piracy in the late seventeenth century.

\section{Acknowledgement}

The author wishes to express sincere gratitude to Alison Cathcart and Allan Macinnes for their supervision and encouragement of this research. The author also wishes to thank Arne Bialuschewski and Steve Murdoch for their kind help and support.

\footnotetext{
${ }^{1}$ Robert C. Ritchie, Captain Kidd and the War against the Pirates (London, 1986), 1-2.

${ }^{2}$ Arne Bialuschewski, 'Pirates, Slavers and the Indigenous Population in Madagascar, c. 1690-1715', The International Journal of African Historical Studies, Vol. 38, No. 3 (2005), 401 408.

${ }^{3}$ Steve Pincus, 1688: The First Modern Revolution (Connecticut, 2009), 366-399.

${ }^{4}$ Ritchie, Captain Kidd, 28-40; Robert C. Ritchie, 'Kidd, William (c. 1645-1701)' in Oxford Dictionary of National Biography (hereafter ODNB), (Oxford, 2004).

${ }^{5}$ Lawrence H. Leder, Robert Livingston 1654-1728 and the Politics of Colonial New York (New York, 1961), 108-9; Ritchie, Captain Kidd, 40-43.

${ }^{6}$ John D. Runcie, 'The Problem of Anglo-American Politics in Bellomont's New York', The William and Mary Quarterly, Third Series, Vol. 26, No. 2 (Apr., 1969), 191-217.

${ }^{7}$ Leder, Robert Livingston, 101; Ritchie, Captain Kidd, 44-47.

${ }^{8}$ Pincus, 1688, 393-398.

${ }^{9}$ Henry Horwitz, 'The East India Trade, the Politicians, and the Constitution: 16891702', Journal of British Studies, Vol. 17, No. 2 (Spring, 1978), 7.

${ }^{10}$ Bialuschewski, 'Pirates, Slavers', 401-408.

${ }^{11}$ Leder, Robert Livingston, 109; Pincus, 1688, 393-398.

${ }^{12}$ Leder, Robert Livingston, 109.

${ }^{13}$ Ritchie, Captain Kidd, 51.

${ }^{14}$ Leder, Robert Livingston, 108-109; Ritchie, Captain Kidd, 50-51.

${ }^{15}$ Leder, Robert Livingston, 109.

${ }^{16}$ Ritchie, Captain Kidd, 52.

${ }^{17}$ Anonymous, Journal of the House of Commons, Volume 13, 12-15; Ritchie, Captain Kidd, 53 54.

${ }^{18}$ Ritchie, Captain Kidd, 55.

${ }^{19}$ TNA, CO 5/860, no. 64. Letter from the Earl of Bellomont to the Board relating wholly to his seizing and Committing of Captain Kidd \& ye securing of his effects. Dated at Boston ye 26th July 1699.

${ }^{20}$ TNA, CO 5/860, no. 64 xxv. Copy of Captain Kid's Narrative. Dated July the 7th 1699.

${ }^{21}$ TNA, CO 5/860, no. 64 xxv. Copy of Captain Kid's Narrative. Dated July the 7th 1699; TNA, HCA 1/15, f. 7. The Informations of Robert Bradenham \& Joseph Palmer.

${ }^{22}$ Ritchie, Captain Kidd, 75.

${ }^{23}$ Joel Baer, Pirates (Gloucester, 2007), 100-105.

${ }^{24}$ Ritchie, Captain Kidd, 131-132.

${ }^{25}$ Baer, Pirates, 106-115.
} 
${ }^{26}$ TNA, CO 5/860, no. 64 xxv. Copy of Captain Kid's Narrative. Dated July the 7 th 1699.

${ }^{27}$ TNA, CO 323/2, B49 no. 7 f. 352-353. An Acct of Capn Kidd in the Adventure Galley recd June 8th 1697.

${ }^{28}$ TNA, CO 5/860, no. 64 xi. Copy of ye Examination of Wm Jenkins, Richard

Barlycorn, \& Robt Lamley, three of Kid's Men, taken the 6th \& 8th of July 1699; TNA, CO 5/860, no. 64 xxv. Copy of Captain Kid's Narrative. Dated July the 7th 1699; TNA, HCA 1/15, f. 7. The Informations of Robert Bradenham \& Joseph Palmer.

${ }^{29}$ Malyn Newitt, The Comoro Islands: Struggle Against Dependency in the Indian Ocean

(Hampshire, 1984), 20.

${ }^{30}$ TNA, CO 323/2, B49 no. 7 f. 352-353. An Acct of Capn Kidd in the Adventure Galley recd June 8th 1697.

${ }^{31}$ Ibid.

${ }^{32}$ TNA, CO 5/860, no. 64 xxv. Copy of Captain Kid's Narrative. Dated July the 7th 1699.

${ }^{33}$ TNA, CO 5/860, no. 64 xviii. Copy of ye Examination of Hugh Parrots one of Kid's men. Dated the 10th July 1699.

${ }^{34}$ TNA CO 323/2, B50 no. 2 f. 372-373. The Deposition of Nich- Alderson Mariner \& Dutchman about 45 years of age. Sworn at Bombay 19th 8ber 1697; TNA, HCA 1/15, f. 7. The Informations of Robert Bradenham \& Joseph Palmer.

${ }^{35}$ TNA, HCA 1/15, f. 7. The Informations of Robert Bradenham \& Joseph Palmer.

${ }^{36}$ Ritchie, Captain Kidd, 93-94.

${ }^{37}$ TNA CO 323/2, B50 no. 2 f. 372-373. The Deposition of Nich- Alderson Mariner \& Dutchman about 45 years of age. Sworn at Bombay 19th 8ber 1697; TNA, HCA 1/15, f. 7. The Informations of Robert Bradenham \& Joseph Palmer.

${ }^{38}$ Ibid.

${ }^{39}$ Ritchie, Captain Kidd, 99.

${ }^{40}$ TNA, HCA $1 / 15$, f. 7 . The Informations of Robert Bradenham \& Joseph Palmer.

${ }^{41}$ TNA, CO 323/2, B49 no. 11 f. 354. Clause of the Lre from Carwar to Bombay dat 9th Augst 97, concerning Capt Kidd in ye Adventure Galley. Also Copy of Capt Kidds Lre to the Chief etc at Callicutt Oct ye 4th 1697; TNA, CO 323/2, B50 no. 1 f. 370-371. The Deposition of Benjamin Franks aged about 47 years (who came out in the Adventure Gally a Privateer Captain William Kid Commandr) Inhabitant of New York. Sworn at Bombay 10 October 1697; TNA CO 323/2, B50 no. 2 f. 372-373. The Deposition of Nich- Alderson Mariner \& Dutchman about 45 years of age. Sworn at Bombay 19th 8ber 1697.

42 TNA CO 5/860, no. 64 xii. Copy of ye narrative of Wm Cuthbert late Gunner of ye ship Charles ye 2d. Capn Dorrel Comdr relating to some Piraces committed by Capn Kidd; TNA CO 323/2, B50 no. 2 f. 372-373. The Deposition of Nich- Alderson Mariner \& Dutchman about 45 years of age. Sworn at Bombay 19th 8ber 1697.

${ }^{43}$ TNA CO 5/860, no. 64 xii. Copy of ye narrative of Wm Cuthbert late Gunner of ye ship Charles ye 2d. Capn Dorrel Comdr relating to some Piraces committed by Capn Kidd.

${ }^{44}$ TNA, CO 5/860, no. 64 xxv. Copy of Captain Kid's Narrative. Dated July the 7th 1699.

${ }^{45}$ Anonymous, Complete Collection of State-trials and Proceedings, 290.

${ }^{46}$ TNA, CO 5/860, no. 64 xxv. Copy of Captain Kid's Narrative. Dated July the 7 th 1699.

${ }^{47}$ Anonymous, Complete Collection of State-trials and Proceedings, 291-293.

${ }^{48}$ Ibid. 
${ }^{49}$ TNA, CO 5/860, no. 64 xi. Copy of ye Examination of Wm Jenkins, Richard Barlycorn, \& Robt Lamley, three of Kid's Men, taken the 6th \& 8th of July 1699; TNA, CO 5/860, no. 64 xxv. Copy of Captain Kid's Narrative. Dated July the 7th 1699; TNA, HCA $1 / 15$, f. 7 . The Informations of Robert Bradenham \& Joseph Palmer.

${ }^{50}$ TNA, HCA 1/15, f. 7. The Informations of Robert Bradenham \& Joseph Palmer.

${ }^{51}$ Anonymous, Complete Collection of State-trials and Proceedings, 292,

${ }^{52}$ Ritchie, Captain Kidd, 108; TNA, CO 5/860, no. 64 xxv. Copy of Captain Kid's Narrative. Dated July the 7th 1699.

${ }^{53}$ TNA, CO 5/860, no. 64 xxv. Copy of Captain Kid's Narrative. Dated July the 7th 1699.

${ }^{54}$ Ritchie, Captain Kidd, 108; TNA, CO 5/860, no. 64 xi. Copy of ye Examination of Wm Jenkins, Richard Barlycorn, \& Robt Lamley, three of Kid's Men, taken the 6th \& 8th of July 1699; TNA, CO 5/860, no. 64 xxv. Copy of Captain Kid's Narrative. Dated July the 7th 1699.

${ }^{55}$ TNA, CO 5/860, no. 64 xxv. Copy of Captain Kid's Narrative. Dated July the 7th 1699.

${ }^{56}$ Ibid.

${ }^{57}$ Ibid.

${ }^{58}$ TNA, HCA $1 / 15$, f. 7 . The Informations of Robert Bradenham \& Joseph Palmer.

${ }^{59}$ TNA, CO 5/860, no. 64 xi. Copy of ye Examination of Wm Jenkins, Richard

Barlycorn, \& Robt Lamley, three of Kid's Men, taken the 6th \& 8th of July 1699; TNA, HCA $1 / 15$, f. 7 . The Informations of Robert Bradenham \& Joseph Palmer.

${ }^{60}$ Ritchie, Captain Kidd, 127.

${ }^{61}$ Anonymous, Complete Collection of State-trials and Proceedings, 335.

${ }^{62}$ See TNA CO 5/860, no. 64 viii. Copy of the Examination of Gabriel Loffs one of Kid's crew before the Earle of Bellomont \& Council 10th July 1699; TNA, CO 5/860, no 64 xi. Copy of ye Examination of Wm Jenkins, Richard Barlycorn, \& Robt Lamley, three of Kid's men, taken 6th \& 8th of July 1699; TNA, CO 5/860, no 64 xviii. Copy of ye Examination of Hugh Parrots one of Kid's men. Dated the 10th July 1699; TNA, HCA 1/15, f. 7. The Informations of Robert Bradenham \& Joseph Palmer.

${ }^{63}$ E.B. O'Callaghan, Documents relative to the colonial bistory of the state of New York, Vol IV, 762-765; Ritchie, Captain Kidd, 160-164.

${ }^{64}$ TNA, CO 5/860, no. 64 xi. Copy of ye Examination of Wm Jenkins, Richard Barlycorn, \& Robt Lamley, three of Kid's Men, taken the 6th \& 8th of July 1699; TNA, CO 5/860, no. 64 xxv. Copy of Captain Kid's Narrative. Dated July the 7th 1699.

${ }^{65}$ TNA, HCA $1 / 15$, f. 36. By the King, A Proclamation. Given the eighth day of December, 1698.

${ }^{66}$ Anonymous, Journal of the House of Commons, Volume 13, 16; Ritchie, Captain Kidd, 165.

${ }^{67}$ TNA, CO 5/860, no. 64 xi. Copy of ye Examination of Wm Jenkins, Richard Barlycorn, \& Robt Lamley, three of Kid's Men, taken the 6th \& 8th of July 1699; TNA, CO 5/860, no. 64 xxv. Copy of Captain Kid's Narrative. Dated July the 7th 1699.

${ }^{68}$ TNA, CO 5/860, no. 62. The Earl of Bellomonts letter to Lords of the Committee of Trade about his seizing \& committing of Kidd ye Pirate. Dated the 8th July 1699; TNA, CO 5/860, no. 64. Letter from the Earl of Bellomont to the Board relating wholly to his seizing and Committing of Captain Kidd \& ye securing of his effects. Dated at Boston ye 26th of July 1699.

${ }^{69} \mathrm{Ibid}$; TNA, CO 5/860, no. 64 vii. Copy of ye E. of Bellomonts Lre to Mr Gardiner to deliver parcel of Gold left with him by Capn Kidd. Dated ye 8th July 1699.

${ }^{70}$ Ritchie, Captain Kidd, 192. 
${ }^{71}$ Stuart Handley, 'Talbot, Charles, duke of Shrewsbury (1660-1718)' in ODNB (Oxford, 2004); Stuart Handley, 'Whig junto (act. c.1694-c.1716)', ODNB (Oxford, 2004); Ritchie, Captain Kidd, 185-186.

${ }^{72}$ Horwitz, East India, 9-11.

${ }^{73}$ Virginia Bever Platt, 'The East India Company and the Madagascar Slave Trade', The William and Mary Quarterly, Third Series, Vol. 26, No. 4 (1969), 553.

${ }^{74}$ David Ormrod, The Rise of Commercial Empires: England and the Netherlands in the Age of Mercantilism, 1650-1770 (Cambridge, 2003), 44-46.

75 'Mr. Vernon to the Duke of Shrewsbury, August 8, 1699', G. P. R. James (ed.), Letters Illustrative of the Reign of William III from 1696 to 1708. Addressed to the Duke of Shrewsbury by James Vernon, Esq. Secretary of State. Now first published from the originals, Volume II (London, 1841), 335-337.

76 'Mr. Vernon to the Duke of Shrewsbury, September 21, 1699', James, Letters Illustrative, 353-354.

${ }^{77}$ Ibid.

${ }^{78}$ 'Mr. Vernon to the Duke of Shrewsbury, December 2, 1699', James, Letters Illustratrative,,371-373.

${ }^{79}$ Ibid.

80 'Mr. Vernon to the Duke of Shrewsbury, December 5, 1699', James, Letters Illustratrative, 374-376; 'Mr. Vernon to the Duke of Shrewsbury, December 7, 1699', James, Letters Illustratrative, 376-381.

${ }^{81}$ 'Mr. Vernon to the Duke of Shrewsbury, April 16, 1700', James, Letters Illustrative, 2936; Ritchie, Captain Kidd, 192-196.

82 'Mr. Vernon to the Duke of Shrewsbury, April 16, 1700', James, Letters Illustrative, 29-36

${ }^{83}$ Ritchie, Captain Kidd, 192-201

${ }^{84}$ Anonymous, Complete Collection of State-trials and Proceedings, 287.

${ }^{85}$ TNA, ADM 1/2004. Capt Kidd letter from Newgate 23d of April 1701.

${ }^{86}$ Ritchie, Captain Kidd, 208-209.

${ }^{87}$ Anonymous, Complete Collection of State-trials and Proceedings, 287-338.

${ }^{88}$ Ritchie, Captain Kidd, 201.

${ }^{89}$ Horwitz, 'East India Trade', 16-18.

${ }^{90}$ Ritchie, Captain Kidd, 226-227.

${ }^{91}$ Ormrod, Commerical Empires, 46 